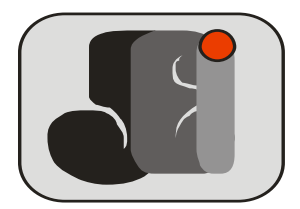

\title{
Data Screening and Preliminary Analysis on The Impact of Rural Infrastructure on Rice Productivity in Kano State, Nigeria
}

\author{
Yusuf Tanko ${ }^{* 1}$, Chea Yong Kang ${ }^{2}$, Rabiul Islam ${ }^{3}$ \\ ${ }^{1}$ OYA Graduate School Business, School of Economics, Finance and Banking, Universiti Utara Malaysia 06010 UUM Sintok, Kedah, Malaysia. \\ ${ }^{2}$ School of Economics, Finance and Banking, COB, Universiti Utara Malaysia 06010 UUM Sintok, Kedah, Malaysia. \\ ${ }^{3}$ School of International Studies, COLGIS, Universiti Utara Malaysia 06010 UUM Sintok, Kedah, Malaysia.
}

* Corresponding author: ytanko64@gmail.com

\begin{abstract}
Despite having vast farmland suitable for paddy rice farming, local production in the country is weak, especially in Kano where the state has the most abundant farmland put to rice farming and the most extensive rice farmers in the 36 states of the country. As such, over $4 \mathrm{~mm} / \mathrm{t}$ of milled paddy rice has to be imported annually into Nigeria to supplement home production. The economy cannot sustain rice import because it depends on crude oil revenue; thus, leading to scarcity of rice at an exorbitant price. The study was conducted in the 2018 cropping season for rainfed and irrigated paddy rice, to identify the impact of rural infrastructure on the productivity of rice farmers in Kano State, Nigeria. There are seven local governments with 17 rice clusters in the state that are cultivating rice. A random sample of 768 rice farmers was selected in 9 rice clusters from the population of 135,895 rice farmers using multistage and purposive sampling. Using the Statistical Package for Social Science (SPSS) software version 22, data screening and preliminary analysis was conducted, aimed at satisfying the assumptions of the multivariate analysis. Thus, missing data analysis was performed to identify univariate outliers and multivariate outliers. Likewise, normality skewness and kurtosis, as well as multicollinearity issues, were checked. The preliminary analysis indicates that the data fulfil the conditions of multivariate analysis, thus, suitable for inferences.
\end{abstract}

Keywords: Rural Infrastructure, Preliminary Analysis, Data Screening, Kano State, Rice Farmers
ARTICLE INFORMATION

Received: 27 February 2019 Revised: 16 March 2019 Accepted: 05 April 2019

DOI: $10.31580 /$ jei.v6i2.900

\section{INTRODUCTION}

In any multivariate analysis, data screening is an important aspect that lays the foundation of the results of a quantitative study. As such, it is imperative to identify any likely violation of the underlying assumptions of multivariate analysis through data screening (Hair Jr., Black, \& Anderson, 2010). Therefore, the quality of the outcome of the study and acceptability depends on the data screening though; researchers mostly skip this stage of research due to its burden (Gorondutse \& Hilman, 2014; Maiyaki \& Moktar, 2011). The absence of data screening often leads to poor quality of the result and accuracy of the type of analysis used. Although Tabachnick and Fidell (2013) believed that the screening could be performed by proofreading of the original data generated from the computer file. However, proofreading may only apply to a small data set, but when the data is large, it is cumbersome to proofread the data on a computer. Thus, the need to examine the data using computer software for descriptive statistics, since the computer software exposes hidden errors that might not be discovered through proofreading (Hair Jr. et al., 2010).

Furthermore, data screening raises the awareness of the researcher on the interrelationship among the variables. Thus, it enables articulated result interpretation; fulfilling the assumptions of multivariate data analysis is achieved. Hence, as recommended by Hair Jr. et al. (2010), the study examined issues concerning missing values, outliers, multicollinearity, and response bias.

\section{LITERATURE REVIEW}

Literature such as (Antle, 1984; Binswanger, Khandker, \& Rosenzweig, 1993; Cook, 2011; Craig, Pardey, \& Roseboom, 1997; Gajigo \& Lukoma, 2011; Kiprono \& Matsumoto, 2014; Llanto, 2012; Lokesha \& Mahesha, 2016; Lozano-Espitia \& Ramírez-Villegas, 2016; Manjunath \& Kannan, 2015; Narayanamoorthy \& Hanjra, 2006; Teruel \& Kuroda, 2005; Zhang \& Fan, 2004) have shown that infrastructure has a significant impact on the farmers' productivity.

\section{Road Networks}

Billions of people worldwide were disconnected to the workplace, health care facilities, credit facilities, and educational opportunities due to the absence of road or high cost of transportation (Mikou, Rozenberg, Koks, Fox, \& Peralta Quiros, 2019). Access to the all-season rural road network will significantly increase the welfare of rural farmers. Hence, rural roads network connects farmers with their farmlands, inputs, and outputs markets, as well as expanding farmers' accessibility to credits (Dercon, Gilligan, Hoddinott, \& Woldehanna, 2009). Even though, Pavel and Moldovan (2019) reported that within short a period, there is an insignificant influence of roads network with local economic development. 


\section{Farm Size}

The size of the farm affects output produced as reported by Akudugu (2016) and Tashikalma, Giroh, and Ugbeshe (2014) that the size of the farm significantly affects rice production. Also, Osanyinlusi and Adenegan (2016) indicate that farm size has a significant positive impact on the efficiency of rice production. Furthermore, Ragasa and Chapoto (2017) reported that out of the $7.5 \%$ increase in rice productivity, $6 \%$ is attributed to expansion in the land area. Also, Bhattacharyya and Mandal (2016) and Wang, Chen, Gupta, and Huang (2015) reported an increase in yield due to a growth in farm size and yield decreases with land fragmentation.

Yan, Chen, and Hu (2019) report an inverted-U shape correlation between farm size and output efficiency, and farm size and profit efficiency in agricultural production in China, and Sheng, Ding, and Huang (2019) shows an inverse relationship between farm size and productivity in most small size farms. Further, the choice of labour or capital intensive may smooth the non-linearity of farm size and productivity relationship. At large scale production, it is more likely that capital intensive will affect the relationship between farm size and productivity. Thus, preparing farmers to be capital intensive is better than subsidizing rent to acquire more land with labour-intensive.

Similarly, Zhong, Zhu, Chen, Liu, and Cai (2019) obtained an inverted U-shaped relationship between farm size and technical efficiency for farmers that combined farming with other business. Moreover, the farm size technical efficiency increases with the level of engagement in other enterprises. Further, the variation in technical efficiency of involvement depends on the farm size. Hence, eliminating technical inefficiency will increase crop yield by $12 \%$. Also, the result of a study by Ren et al. (2019) shows an increase in farm size has a positive effect on the net profit of a farmer, economic, technical, and labour efficiency.

Furthermore, an increase in farm size significantly reduces the use of fertilizer and pesticides. Expansion in large-scale farming is a step forward to revolutionizing agricultural practices. Also, to attain food security in a country even though there is a poor understanding of allocative efficiency, which requires further research.

\section{Irrigation Facilities}

A study by Gajic, Kresovic, Tapanarova, Zivotic, and Todorovic (2018) shows in the semi-dry and dry period; a quadratic relationship exists between yield and watering. Thus, irrigation becomes necessary for semi-dry and dry periods. Therefore, the availability and utilization of irrigation facility would increase rice yield (Ahmed, Xu, Yu, \& Wang, 2017). Similarly, Chun et al. (2016) report an improvement in irrigation facilities led to an increase in rice yield from $8.2 \%$ to $42.7 \%$. This is because expansion in irrigated land increases rice productivity (Ragasa \& Chapoto, 2017). However, the scarcity of water causes a severe loss to world crop and is expected to worsen. It was reported by Comas, Trout, DeJonge, Zhang, and Gleason (2019) that water stress led to a decline in yield but can be revegetated through irrigation. This led to the development of some-water saving management practices in areas where agriculture depends on irrigation, to increase yield.

Maneepitak et al. (2019) reported that the alternate wetting and drying increases crop yield by $15 \%$ during the wet season, $7 \%$ in the dry season, and yield more output compared to continuous flooding. It further reduces water input by $19 \%$ in the wet season and $39 \%$ during the dry season, leading to an improvement in the productivity

of water by $46 \%$ during the wet season and $77 \%$ in the dry season. Though the study by Yamaguchi, Tuan, Minamikawa, and Yokoyama (2019) shows, farmers are in favour of continuous flooding.

\section{Electricity Supply}

Electrifying rural areas will promote productive activities in the region by reducing the cost of maintenance and back up. While the inadequate amount of electricity in the rural areas distorts productive activities of the rural people (Narula \& Bhattacharyya, 2017). Barnes and Binswanger (1986) reported that private rural electrification significantly affects agricultural productivity. Though $\mathrm{Li}$, Chen, and Liu (2019) reported that individual energy is expensive, therefore cannot be accessed by rural dwellers. Also, electrifying pumps increase investment in irrigation by $28 \%$ and output by $2 \%$ (Binswanger et al., 1993) while, subsidy removal in electricity causes food inflation ( $R$. Bhattacharyya \& Ganguly, 2017). Thus, Langarita, Chóliz, Sarasa, Duarte, and Jiménez (2015) advocate for a low tariff on electricity to the rural dwellers.

\section{Communication Network}

Communication is a vital tool for farmers as reported by Elly and Silayo (2013) that farmers are using traditional interface to source data on agriculture. The modern communication system bridges the gap in the data anomalies, reduces the gap in accessing and conveying inputs and outputs. For instance, mobile phones nowadays ease the adoption of technology through information and computer technology agricultural extension programs. It was reported by Kirui, Okello, Nyikal, and Njiraini (2013) that the services of MMT increase commercial agriculture by $37 \%$ annually.

Khanna and Kaur (2019) reported that internet of thing has a significant impact on modern agriculture. The internet of thing enables farmers to regulate the management of agricultural activities using remote sensing effectively. Further, the internet of thing minimizing human effort, saving time, increasing yield and profit. The media preference of farmers is motivating and engaging media like practical demonstration or television, then mobile phones due to its convenience, and books for details (Moyo \& Salawu, 2019).

\section{Fertilizer Access}

The expedient modern means of increasing the productivity of crop is enhancing micronutrient (Tiwasing, Dawson, \& Garrod, 2019). Tashikalma et al. (2014) and Zhu and Chen (2002) reported that chemical fertilizer positively affects crop production. Also, Stewart, Dibb, Johnston, and Smyth (2005) report that the nutrients of fertilizer upsurge crop yield from $30 \%$ to $50 \%$. Furthermore, fertilizer usage seasonally increases crop return by $35 \%$ and annually by $69 \%$ (Duflo, Kremer, \& Robinson, 2008).

Also, Zhang et al. (2017) reported that nitrogen significantly increases the growth rate of crop and rice yield. Similarly, a study by Osanyinlusi and Adenegan (2016) and Mandal, Patra, Singh, Swarup, and Masto (2007) shows that the usage and quantity used of fertilizer positively affect the productivity of farmers. Moreover, a comparative study result shows a further increase in rice yield can be attained using fertilizer in Hainan, China and Niger, Nigeria (Ahmed et al., 2017). Thus, Ajani and Ugwu (2008) recommend supplying fertilizer in the right place and time.

\section{Access to Credit}

Access to formal and informal credit facilities have a positive and significant impact on agricultural production (Akudugu, 2016; Nan, Gao, \& Zhou, 2019). Insufficient finance becomes a key obstacle to rice productivity Ojochenemi, Gabriel, and Ogwuche (2017), and a significant setback to modern technology adoption (Hena, Jingdong, Zhang, Memon, \& Khalil, 2019). Besides, a study by Hena et al. (2019) and 
Nonvide, Sarpong, Kwadzo, Anim-Somuah, and Gero (2017) shows access to adequate credit facility increases the productivity of farmers, eases proper utilization of inputs, permits new technology adoption, and provides an opportunity for enhancing technical skills.

Moreover, Binswanger et al. (1993) reported that the fast growth of banks, resulted to an increase in fertilizer demand by $23 \%$, raised pumps investment by $41 \%$, raised tractor investment by $13 \%$, and upsurged crop harvest by $3 \%$. Unfortunately, most banks shine away from rural banking due to the enormous risks involved. ljaiya, Abdulraheem, and Abdullahi (2017) opined that banks shine away businesses which involve considerable uncertainties, particularly in the rural areas. Thus, financial institutions prefer business in the regions that have excellent infrastructure with relatively fewer risks in agriculture (Binswanger et al., 1993).

Nyaga and Nzulwa (2017) indicated that the inability of farmers to access credit is due to poor awareness and the managerial skills required by the farmers. Also, Islam and Siwar (2012) reported that systematized farmers have more access to formal funding than un-organized farmers. Similarly, a study by Roberts, Otieno, and Nyikal (2017) shows that farmers with bank account have more access to a formal credit facility compared to those without a bank account and that, a significant negative correlation exists between access to credit and literacy, profession, and group membership, Abdallah, Ayamga, and Awuni (2019) indicates gender, age, literacy, farm size, labour, wealth and group membership significantly determine credit access, and Bai, Shi, Liu, and Sarkis (2019) opined creditworthiness depends on education and skills of the farmer.

\section{Access to Market}

An improvement in accessing market by the rural farmers increases crop productivity (Koppmair, Kassie, \& Qaim, 2016). Bohl and Sulewski (2019) reported that the short-long term activities of speculators under scrutiny lessen the volatility rate in the markets. Further, Kaminski and Christiaensen (2014) report that market facilities reduced the risk related to postharvest losses. Hence, access to the market by rural farmers facilitate an increase in agricultural productivity. Therefore, Uduma, Samson, and Mure (2016) emphasized in having a supportive market in rural areas. Czyzewski and Majchrzak (2017) and Goto and Douangngeune (2017) suggest government intervention to support rural markets.

Similarly, Binswanger et al. (1993) maintained that controlled markets led to a growth rate of $87 \%$, contributes $4 \%$ to agricultural output, and $17 \%$ to the demand for fertilizer, lift farmers liquidity position, and cut down the costs of business for banks and farmers. Further, Uduma et al. (2016) opined that weak supportive market in the rural areas is a constraint to increasing rice productivity though Akudugu (2016) reported that access to a market is not significantly correlated to agricultural productivity.

\section{Access to Extension Services}

The term extensions refer to the services offered by extension workers to farmers on ways of increasing crop productivity (Antle, Zhang, Mu, Abatzoglou, \& Stöckle, 2018; Golan \& Kohli, 2013). Also, extensions can be practical through contact with farmers or by publications or by radio programs. The latter is preferred due to its broader coverage and in the physical absence of extension agent (Adekunle et al., 2004). A study by Binam, Tonyè, Wandji, Nyambi, and Akoa (2004) shows an increase in groundnut returns of $77 \%$, maize $73 \%$, and cropping maize and groundnut $75 \%$ as a result of extensions offered to farmers. Also, Dercon et al. (2009) report that one extension visits led to a reduction of poverty by $9.8 \%$ and upsurge consumption by $7.1 \%$. Owens, Hoddinott, and Kinsey (2003) report one to two extension visits led to a rise in crop yield by $15 \%$.

Furthermore, a study by Alene and Manyong (2007), Jin, Huang, Hu, and Rozelle (2002), Maffioli, Ubfal, Vazquez-Bare, and Cerdan-Infantes (2013), and Pender and Gebremedhin (2007) shows a significant impact of extensions on modern agriculture adaptations. So, Berhanu and Poulton (2014) opined that an efficient program of increasing farmers productivity is an investment in extensions as Jin and Huffman (2016) reported a high return on investment in extensions. Therefore, Garnett et al. (2013) stressed extension services to back an increase in farmers productivity. Birkhaeuser and Evenson (1991) affirmed that most research results on extension investment show a return of more than $40 \%$. Thus, concludes that estimates were consistent, extension services increase agricultural productivity. Though farmers negatively perceived agricultural extension services (Al-Zahrani, Khan, Baig, Mubushar, \& Herab, 2019).

\section{METHODOLOGY}

In assessing the data for this study, the descriptive and inferential statistics were carried out using the SPSS version 22 software. Consequently, Mahalanobis distance and correlation analysis were performed. The sample for the study was collected from the rice farmers in the 17 rice clusters of the 7 local governments of Kano state that are cultivating paddy rice. The multistage sampling technique was used to select the local governments for the study - further a random selection of 768 rice farmers from a population of 135,685 in 9 rice clusters. A total of 656 usable questionnaires were retrieved from the 9 rice clusters.

\section{RESULTS AND DISCUSSION}

This segment presents the result and discussion of the data collected for the study.

\section{Descriptive Statistics of the Respondents}

Table 1 present the summary of sex, age qualification, marital status, and experience of the respondents in the study area. From Table 1, there are 131 female rice farmers and 525 male rice farmers, indicating there are more male rice farmers than female rice farmers. The age group of the respondents shows that farmers who are below the age of 20 years rice farmers are 84, 20-29 years are 134, 30-39 years are 212, 4049 years are 151 , and 50 and above years are 151 . This shows that $55.5 \%$ of the rice farmers are within the working population group age bracket 30-49 years, with a prospect for young farmers age bracket below $20-29$ years of $33.2 \%$. Also, $23.9 \%$ of the respondents have at least a primary certificate, but $59.4 \%$ have secondary and above education. Further, the Table shows that $73.9 \%$ of the respondents are married, and $77.6 \%$ have more than 5 years of rice farming experience.

\section{Response Rate}

The number of questionnaires distributed was 768 in the 9 rice clusters, out of which 739 were returned representing $96.22 \%$. However, the usable questionnaires were 656 as 83 were deleted in the process of data cleaning, representing a reasonable response rate of $85.42 \%$. Further, the response rate from each rice cluster is reasonable, ranging from $78.67 \%$ to $88 \%$, with no cluster having a poor response rate.

\section{Test of Non-Response Bias}

The non-response bias in a survey refers to the failure to get the required information from the respondents, which can affect the findings of the study. Hence, the need to assess such 
error before continuing with the analysis. No below minimum bias response rate nor maximum, which a study estimate is inevitably biased (Singer, 2006). In addressing this problem, $100 \%$ was added to the computed sample as recommended by Salkind (1997).

\begin{tabular}{llll}
\multicolumn{3}{l}{ Table 1. Summary of Respondents' Demography } \\
\hline S/No. & Items & Frequency & Percentage \\
\hline 1 & Sex & 131 & 20 \\
& Female & 525 & 80 \\
& Male & & \\
& Age & 84 & 12.8 \\
& Below 20 years & 134 & 20.4 \\
& 20-29 years & 212 & 32.3 \\
& 30-39 years & 151 & 23.0 \\
& 40-49 years & 75 & 11.4 \\
& 50 and above years & & \\
3 & Qualification & 169 & 16.6 \\
& No formal education & 157 & 23.9 \\
& Primary education & 32.3 \\
& Secondary education & 212 & 27.1 \\
& Tertiary education & 178 & \\
4 & Marital status & & 26.1 \\
& Single & 171 & 73.9 \\
& Married & 485 & \\
5 & Experience & & 22.4 \\
& 1-5 years & 147 & 35.1 \\
& 6-10 years & 230 & 42.5 \\
\hline
\end{tabular}

Table 2. Response Rate of the Questionnaires

\begin{tabular}{|c|c|c|c|c|c|c|c|}
\hline \multirow[t]{2}{*}{ Cluster } & \multicolumn{7}{|c|}{ Questionnare } \\
\hline & 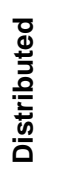 & 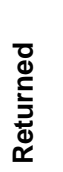 & 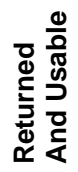 & 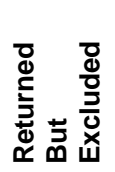 & 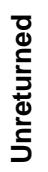 & 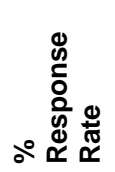 & 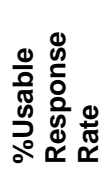 \\
\hline Lautaye & 75 & 70 & 66 & 4 & 5 & 93.33 & 88 \\
\hline Dokasati & 75 & 72 & 66 & 6 & 3 & 96 & 88 \\
\hline GarinAli & 80 & 75 & 69 & 6 & 5 & 93.75 & 86.25 \\
\hline Kadawa & 80 & 77 & 66 & 11 & 3 & 96.25 & 82.5 \\
\hline Bugau & 75 & 73 & 59 & 14 & 2 & 97.33 & 78.67 \\
\hline Karfi & 100 & 96 & 88 & 8 & 4 & 96 & 88 \\
\hline Kura & 90 & 88 & 78 & 10 & 2 & 97.78 & 86.67 \\
\hline Nata'ala & 75 & 73 & 64 & 9 & 2 & 97.33 & 85.33 \\
\hline $\begin{array}{l}\text { Larabar } \\
\text { G/Sarki }\end{array}$ & 118 & 115 & 100 & 15 & 3 & 97.46 & 84.75 \\
\hline 9clusters & 768 & 739 & 656 & 83 & 29 & 96.22 & 85.42 \\
\hline
\end{tabular}

Further, extension workers, research assistants were used with some inducements, followed by phone calls and text messages, in motivating rice farmers to participate, so that the required information can be obtained (Churchill \& lacobucii, 2004). The likely variance among the early and late response was compared using the entire study variables. The returned questionnaires were recorded based on early and late responses, and an independent T-test was carried out to ascertain the existence of differences between the two groups, as presented in Table 3 and Table 4 below.

The result of Table 3 shows no stern difference in the group mean and standard deviation for the early response and late response, except the response on farm size, irrigation, and communication. The 2-tail t-test result Table 4 shows that there is no significant disparity with respect to the early and late respondents based on Road networks ( $t-0.064, p<0.949$ ), electricity supply ( $\mathrm{t} 0.103, \mathrm{p}<0.918$ ), access to fertilizer ( $\mathrm{t}$ 1.252, $\mathrm{p}<0.211$ ), access to market (t $0.174, \mathrm{p}<0.862$ ), access to credit ( $\mathrm{t} 0.478, \mathrm{p}<0.633$ ), and access to extension services ( $\mathrm{t}$ $1.445, p<0.149$ ). While, Farm size (t 3.971, $p<000$ ), irrigation facilities ( $\mathrm{t} 5.606, \mathrm{p}<000$ ), and communication networks (t
5.214, $\mathrm{p}<000$ ) shows a disparity between the early and late respondents. So, based on the tests result in Tables 3 and Table 4 (Appendix -A), a conclusion can be drawn that there is no problem of response bias

Table 3. Group Descriptive Statistics for Early and Late Respondents

\begin{tabular}{|c|c|c|c|c|c|}
\hline & Group & $\mathbf{N}$ & Mean & $\begin{array}{l}\text { Std. } \\
\text { Deviation }\end{array}$ & $\begin{array}{l}\text { Std. Error } \\
\text { Mean }\end{array}$ \\
\hline \multirow{2}{*}{ Rdn } & Early & 485 & 4.0572 & .66839 & .03035 \\
\hline & Late & 171 & 4.0614 & .90904 & .06952 \\
\hline \multirow{2}{*}{ Fsz } & Early & 485 & 4.4532 & .51633 & .02345 \\
\hline & Late & 171 & 4.1888 & .81475 & .06231 \\
\hline \multirow{2}{*}{$\operatorname{Irg}$} & Early & 485 & 4.0716 & .75130 & .03411 \\
\hline & Late & 171 & 3.5629 & 1.09983 & .08411 \\
\hline \multirow{2}{*}{ Etr } & Early & 485 & 3.3795 & .98211 & .04460 \\
\hline & Late & 171 & 3.3699 & 1.23828 & .09469 \\
\hline \multirow[b]{2}{*}{ Com } & Early & 485 & 4.4620 & .53215 & .02416 \\
\hline & Late & 171 & 4.0629 & .94988 & .07264 \\
\hline \multirow[b]{2}{*}{ Ftz } & Early & 485 & 3.3588 & .45044 & .02045 \\
\hline & Late & 171 & 3.4196 & .75569 & .05779 \\
\hline \multirow{2}{*}{ Mkt } & Early & 485 & 3.2660 & .72676 & .03300 \\
\hline & Late & 171 & 3.2535 & .99926 & .07642 \\
\hline \multirow{2}{*}{ Crd } & Early & 485 & 2.9190 & .77713 & .03529 \\
\hline & Late & 171 & 2.8837 & .96563 & .07384 \\
\hline \multirow{2}{*}{ Ext } & Early & 485 & 2.8146 & .91842 & .04170 \\
\hline & Late & 171 & 2.9368 & 1.03998 & .07953 \\
\hline
\end{tabular}

Data Examination, Screening and Preparation

The screening, editing, and preparation are vital steps to be taken before multivariate analysis to identify whether the underlying assumptions of multivariate were violated (Hair Jr et al., 2010). Further, the data examination allows the researcher to have a deep sympathetic of the data obtained; hence, missing data, outliers, normality, and multicollinearity were checked and treated accordingly.

\section{Analysis of Missing Data}

Given the effect of missing data in the analysis, a protective strategy was used by the researcher at the collection point to reduce the rate of missing data. On the receipt of the returned completed questionnaire, the extension workers, research assistants, and researcher often checked to ensure proper filling of all the questions. Where an item(s) was not filled, politely the attention of the respondent is drawn to complete it (Maiyaki \& Moktar, 2011). Though Hair Jr. et al. (2010) recommends replacement of missing values using mean when it is less than $5 \%$ per item. Thus, the missing value analysis in this study showed one case of missing values of 2 and was treated in SPSS version 22, using the SMEANS.

\section{Analysis of Outliers}

Another vital segment of data screening in a survey study is the assessment of outliers. An outlier is an extreme score that can alter the outcomes of a result (Maiyaki \& Moktar, 2011). The outlier can have a higher or lower value compared to remaining scores in a question, thereby making the examination stance out from the remaining (Hair Jr. et al., 2010). The multivariate analysis may confirm the detection and handling of outliers. In this regards, univariate and multivariate analysis was conducted to detect the outliers. The univariate outliers were checked using the SPSS by detecting cases with large $z$-score values exceeding 3.29 which are considered as potential univariate outliers, and such response was deleted from the analysis (Tabachnick \& Fidell, 2013).

Furthermore, the Mahalanobis Distance (D) was conducted to discover and deal with multivariate outliers (Hair Jr. et al., 2010). Thus, Mahalanobis test was conducted in SPSS and compared with the Chi-square table (Tabachnick \& Fidell, 
2013). The items adapted were 41 , representing 40 degrees of freedom in the $\mathrm{X} 2$ table with $\mathrm{P}<0.001$; the standard is 73.402 (Tabachnick \& Fidell, 2013). This infers that any figure with a Mahalanobis Distance of 73.402 and higher is a multivariate outlier thus should be deleted. As such, no cases were established to be 73.402 and above, implying no multivariate outliers.

\section{Normality Test}

Normality of the data collected for the study was checked. Normality test is a significant supposition in a multivariate analysis that pacts with the flora of data flow for an individual construct and its association to a normal distribution (Hair Jr. et al., 2010; Tabachnick \& Fidell, 2013). In checking the normality of the data, skewness and kurtosis statistics was used (Hair et al., 2010). Though, when the sample for the study is greater than 200 like the present study with 768 samples, the deviation from the normality of skewness and kurtosis sometimes may not show a substantive difference in the analysis (Tabachnick \& Fidell, 2013). Moreover, Kline (2011) argued that the absolute value of skewness that is more than 3 and kurtosis value greater than 10 might signify a problem and values greater than 20 can infer a more severe problem. The preliminary test of normality conducted for all the items used in the study shows that the absolute value for skewness is 2 and kurtosis is 6.29 , signifying both are within the accepted range of $<3$ and $<10$ respectively.

\section{Multicollinearity Test}

Multicollinearity is the relationship between two or more variables, and it becomes a problem when the variables relate to one another as high as 0.9 or more (Pallant, 2007; Tabachnick \& Fidell, 2013). This means that the highly correlated variables contain needless information that needs to be reduced, as not all are required for the analysis because they increase the size of the error term and the standard error of the regression coefficient. Thus, the statistical significance of the coefficients becomes weak. Therefore, Hair Jr. et al. (2010) and Pallant (2007) recommends the use of tolerance and Variance Inflation Factor (VIF) in examining multicollinearity problem with cut-off points of more than 0.1 and not exceeding 10 respectively. The result from Table 5 shows that the tolerance values range from $0.609-0.876$ significantly higher than 0.10 . Also, the VIF ranges between 1.141-1.643, which is less than 10, thus concluded that the problem of multicollinearity does not exist among the exogenous variables.

Table 5. Multicollinearity Test Based on Tolerance and VIF

\begin{tabular}{lll}
\hline Exogenous Variables & Tolerance & VIF \\
\hline Road Networks & .790 & 1.266 \\
Farm Size & .703 & 1.423 \\
Irrigation Facilities & .788 & 1.269 \\
Electricity Supply & .661 & 1.513 \\
Communication Network & .870 & 1.150 \\
Fertilizer Access & .876 & 1.141 \\
Credit Access & .757 & 1.322 \\
Market Access & .637 & 1.570 \\
Extension Services & .609 & 1.643 \\
\hline
\end{tabular}

Furthermore, to re-affirm the absence of multicollinearity among the exogenous variables, Pearson's correlation was calculated using the SPSS as presented in Table 6 . The scale is that any relationship between variables of 0.9 and above is considered as a problem. Hence, from Table 6 (Appendix - A), the values of the variables range between 0.006-0.420 far below the yardstick, therefore, conclude there is no multicollinearity problem among the variables for this study (Hair Jr. et al., 2010).

\section{CONCLUSION}

The paper examines the data collected using statistical methods to certify the fulfilment of the multivariate assumptions. Though the data presents a small number of missing values which is less than $5 \%$, and are treating under value replacement (Hair, Jr. et al., 2010), using SPSS. Hair (2010) and Tabachnick and Fidell (2013) suggest removing univariate and multivariate from data. Therefore, the identified univariate and multivariate were deleted. Hence, the data is ascertained as normally distributed with no response bias. The screened and cleaned data for the study is now furnished for multivariable analysis.

\section{References:}

Abdallah, A.-H., Ayamga, M., \& Awuni, A. J. (2019). Impact of agricultural credit on farm income under the savanna and transitional zones of Ghana. Agricultural Finance Review, 79(1), 60-84. http://doi.org/http://dx.doi.org/10.1108/09564230910978511

Adekunle, A. A., Onyibe, J. E., Ogunyinka, O. M., Omenesa, Z. E., Auta, S. J., \& Kuyello, A. U. (2004). Agricultural information dissemination: An audience survey in Kano State. International Institute of Tropical Agriculture, (April), 1-20.

Ahmed, A., Xu, S., Yu, W., \& Wang, Y. (2017). Comparative Study on Factors Influencing Rice Yield in Niger State of Nigeria and Hainan of China. International Journal of Agricultural and Food Research [IJAFR], 6(1), 15-25.

Ajani, O. I. Y., \& Úgwu, P. C. (2008). Trend in agricultural economics. Asian Network for Scientific Information, 1(1), 1-7.

Akudugu, A. M. (2016). Agricultural productivity, credit and farm size nexus in Africa: A case study of Ghana. Agricultural Finance Review, 76(2), 288-308. http://doi.org/10.1108/09574090910954864

Al-Zahrani, K. H., Khan, A. Q., Baig, M. B., Mubushar, M., \& Herab, A. H. (2019). Perceptions of wheat farmers toward agricultural extension services for realizing sustainable biological yields. Saudi Journal of Biological Sciences. http://doi.org/10.1016/j.sjbs.2019.02.002

Alene, A. D., \& Manyong, V. M. (2007). The effects of education on agricultural productivity under traditional and improved technology in Northern Nigeria: An endogenous switching regression analysis. Empirical Economics, 32(1), 141-159. http://doi.org/10.1007/s00181-006-0076-3

Antle, J. M. (1984). Human capital, infrastructure, and the productivity of Indian rice farmers. Journal of Development Economics, 14(1), 163-181. http://doi.org/10.1016/0304-3878(84)90048-8

Antle, J. M., Zhang, H., Mu, J. E., Abatzoglou, J., \& Stöckle, C. (2018). Methods to assess between-system adaptations to climate change: Dryland wheat systems in the Pacific Northwest United States. Agriculture, Ecosystems and Environment, 253, 195207. http://doi.org/10.1016/j.agee.2017.03.017

Bai, C., Shi, B., Liu, F., \& Sarkis, J. (2019). Banking credit worthiness: Evaluating the complex relationships. The International Journal of Management Science, 83, 26-38. http://doi.org/10.1016/j.omega.2018.02.001

Barnes, D. F., \& Binswanger, H. P. (1986). Impact of rural electrification and Infrastructure and Agricultural Changes, 1966-1980. Economic And Political Weekly, 21(1), 26-34.

Berhanu, K., \& Poulton, C. (2014). The political economy of agricultural extension in Ethiopia: Economic growth and political control. Development Policy Review, 32(2), 197-213. http://doi.org/10.1111/dpr.12082

Bhattacharyya, A., \& Mandal, R. (2016). A generalised stochastic production frontier analysis of technical efficiency of rice farming: A case study from Assam, India. Indian Growth and Development, 9(2), 114-128.

Bhattacharyya, R., \& Ganguly, A. (2017). Cross subsidy removal in electricity pricing in India. Energy Policy, 100(October 2016), 181-190. http://doi.org/10.1016/j.enpol.2016.10.024

Binam, J. N., Tonyè, J., Wandji, N., Nyambi, G., \& Akoa, M. (2004) Factors affecting the technical efficiency among smallholder farmers in the slash and burn agriculture zone of Cameroon. Food Policy, 29(5), 531-545. http://doi.org/10.1016/j.foodpol.2004.07.013

Binswanger, H. P., Khandker, R. S., \& Rosenzweig, R. M. (1993). How infrastructure and financial institutions affect agricultural output 
and investment in India. Journal of Development Economics, 41, 337-366.

Birkhaeuser, D., \& Evenson, R. E. (1991). The economic impact of agricultural extension: A review. Economic Development \& Cultural Change, 39(3), 607. Retrieved from http://search.ebscohost.com/login.aspx?direct=true\&db=buh\&AN $=9105202609 \&$ site $=$ ehost - live

Bohl, M. T., \& Sulewski, C. (2019). The impact of long-short speculators on the volatility of agricultural commodity futures prices. Journal of Commodity Markets, 1-30. http://doi.org/10.1016/j.jcomm.2019.01.001

Chun, J. A., Li, S., Wang, Q., Lee, W. S., Lee, E. J., Horstmann, N., .. Vang, S. (2016). Assessing rice productivity and adaptation strategies for Southeast Asia under climate change through multi-scale crop modeling. Agricultural Systems, 143, 14-21. http://doi.org/10.1016/j.agsy.2015.12.001

Churchill, J. G. A., \& lacobucii, D. (2004). Marketing Research methodological foundations (9th ed.). Thomson Ensley: Mason, $\mathrm{OH}$

Comas, H. L., Trout, J. T., DeJonge, C. K., Zhang, H., \& Gleason, M. S. (2019). Water productivity under strategic growth stage-based deficit irrigation in maize. Agricultural Water Management, 212 433-440. http://doi.org/10.1016/j.agwat.2018.07.015

Cook, P. (2011). Infrastructure, rural electrification and development. Energy for Sustainable Development, 15(3), 304-313. http://doi.org/10.1016/j.esd.2011.07.008

Craig, J. B., Pardey, G. P., \& Roseboom, J. (1997). International productivity patterns: Accounting for input quality, infrastructure, and research. Journal of Agricultural Economics, 79, 10641076

Czyzewski, B., \& Majchrzak, A. (2017). Market versus agriculture in Poland: Macroeconomic relations of incomes, prices and productivity in terms of the sustainable development paradigm. Technological and Economic Development of Economy, 4913, 1-17. http://doi.org/10.3846/20294913.2016.1212743

Dercon, S., Gilligan, D. O., Hoddinott, J., \& Woldehanna, T. (2009). The impact of agricultural extension and roads on poverty and consumption growth in fifteen Ethiopian villages. American Journal of Agricultural Economics, 91(4), 1007-1021. http://doi.org/10.1111/j.1467-8276.2009.01325.x

Duflo, E., Kremer, M., \& Robinson, J. (2008). How high are rates of return to fertilizer? Evidence from field experiments in Kenya. Quarterly Journal of Econom, 121(2), 635-672. Retrieved from http://www.jstor.org/stable/29730068

Elly, T., \& Silayo, E. E. (2013). Agricultural information needs and Sources of the rural farmers in Tanzania: A case of Iringa rural district. Journal of Library Review, 60(5), 383-395. http://doi.org/10.1108/S1479-3563(2012)000012B005

Gajic, B., Kresovic, B., Tapanarova, A., Zivotic, L., \& Todorovic, M. (2018). Effect of irrigation regime on yield, harvest index and water productivity of soybean grown under different precipitation conditions in a temperate environment. Agricultural Water Management, 210(April), 224-231. http://doi.org/10.1016/j.agwat.2018.08.002

Gajigo, O., \& Lukoma, A. (2011). Infrastructure and agricultural productivity in Africa. Retrieved from www.adb.org

Garnett, T., Appleby, M. C., Balmford, A., Bateman, I. J., Benton, T. G. Bloomer, P., ... Godfray, H. C. J. (2013). Sustainable intensification in agriculture: Premises and policies. Science Magazine, 341(July), 33-34. http://doi.org/10.1126/science.1234485

Golan, A., \& Kohli, H. (2013). Asean dynamism: Agricultural transformation and food security. Global Journal of Emerging Market Economies, 5(1), 3-21. http://doi.org/10.1177/0974910112469267

Gorondutse, A. H., \& Hilman, H. (2014). Effect of business social responsibility (BSR) on performance of SMEs: Data screening and preliminary analysis. Asian Social Science, 10(8), 103-115. http://doi.org/10.5539/ass.v10n8p103

Goto, K., \& Douangngeune, B. (2017). Agricultural modernisation and rural livelihood strategies: the case of rice farming in Laos. Canadian Journal of Development Studies, 5189, 1-20. http://doi.org/10.1080/02255189.2017.1263553

Hair Jr., J. F., Black, J. W., \& Anderson, E. R. (2010). Multivariate data analysis (Seventh Ed). Edinburgh: Pearson Educational Limited.

Hena, S., Jingdong, L., Zhang, O., Memon, U. Q., \& Khalil, I. U. (2019). Measurement of Formal and Informal Sources of Agricultural Credits in China. Journal of Social Sciences and Humanity Studies, 5(1), 21-31. ljaiya, M. A., Abdulraheem, A., \& Abdullahi, I. B. (2017). Agricultural credit guarantee scheme and food security in Nigeria. Ethiopian Journal of Environmental Studies and Management., 10(2), 208218.

Islam, R., \& Siwar, C. (2012). The analysis of urban agriculture development in Malaysia. Journal of Advances in Environmental Biology, 6(3), 1068-1078.

Jin, S., Huang, J., Hu, R., \& Rozelle, S. (2002). The creation and spread of technology and total factor productivity in China's agriculture. American Journal of Agricultural Economics, 84(4), 916-930.

Jin, Y., \& Huffman, W. E. (2016). Measuring public agricultural research and extension and Estimating their impacts on agricultural productivity: New insights from US evidence. Agricultural Economics (United Kingdom), 47(1), 15-31. http://doi.org/10.1111/agec.12206

Kaminski, J., \& Christiaensen, L. (2014). Post-harvest loss in SubSaharan Africa: What do farmers say? Global Food Security, 3(3-4), 149-158. http://doi.org/10.1016/j.gfs.2014.10.002

Khanna, A., \& Kaur, S. (2019). Evolution of Internet of Things (IOT) and its significant impact in the field of Precision Agriculture. Computers and Electronics in Agriculture, 157, 218-231. http://doi.org/10.1016/j.compag.2018.12.039

Kiprono, P., \& Matsumoto, T. (2014). Roads and farming: The effect of infrastructure improvement on agricultural input use, farm productivity and market participation in Kenya. CSAE Conference 2014: Economic Development in Africa, The University of Oxford, 1-41.

Kirui, O. K., Okello, J. J., Nyikal, R. A., \& Njiraini, G. W. (2013). Impact of mobile phone-based money transfer services in agriculture: Evidence from Kenya. Quarterly Journal of International Agriculture, 52(2), 141-162. http://doi.org/10.4018/jictrda.2012010101

Koppmair, S., Kassie, M., \& Qaim, M. (2016). Farm production, market access and dietary diversity in Malawi. Public Health Nutrition 20(02), 325-335. http://doi.org/10.1017/S1368980016002135

Langarita, R., Chóliz, S. J., Sarasa, C., Duarte, R., \& Jiménez, S. (2015). Electricity costs in irrigated agriculture: A case study for an irrigation scheme in Spain. Renewable and Sustainable Energy Reviews, 1-12. http://doi.org/10.1016/j.rser.2016.05.075

Li, J., Chen, C., \& Liu, H. (2019). Transition from non-commercial to commercial energy in rural China: Insights from the accessibility and affordability. Energy Policy, 127, 392-403. http://doi.org/10.1016/j.enpol.2018.12.022

Llanto, G. M. (2012). The Impact of Infrastructure on Agricultural Productivity (Discussion paper 2012-12 No. 12). Infrastructure and agricultural productivity. Philippines. Retrieved from http://www.scopus.com/inward/record.url?eid=2-s2.00028580356\&partnerID=tZOtx3y1

Lokesha, M. N., \& Mahesha, M. (2016). Impact of road infrastructure on agricultural development and rural road infrastructure development programmes in India. International Journal of Humanities and Social Science Invention, 5(11), 1-7.

Lozano-Espitia, I., \& Ramírez-Villegas, L. M. (2016). How productive is rural infrastructure? Evidence on some agricultural crops in Colombia. Borradores de Economía (Vol. 948). Retrieved from http://www.banrep.gov.co/sites/default/files/publicaciones/archiv os/be_948.pdf

Maffioli, A., Ubbal, D., Vazquez-Bare, G., \& Cerdan-Infantes, P. (2013) Improving technology adoption in agriculture through extension services: Evidence from Uruguay. Journal of Development Effectiveness, 5(1), 64-81. http://doi.org/10.1080/19439342.2013.764917

Maiyaki, A. A., \& Moktar, S. M. S. (2011). linfluence of service quality, corporate image and percieved value on customer behavioural responses in the Nigerian Banks: Data screening and preliminary analysis. In International Conference on management (ICM 2011) (pp. 547-568).

Mandal, A., Patra, K. A., Singh, D., Swarup, A., \& Masto, R. E. (2007) Effect of long-term application of manure and fertilizer on biological and biochemical activities in soil during crop development stages. Bioresource Technology, 98(18), 35853592. http://doi.org/10.1016/j.biortech.2006.11.027

Maneepitak, S., Ullah, H., Paothong, K., Kachenchart, B., Datta, A., \& Shrestha, R. P. (2019). Effect of water and rice straw management practices on yield and water productivity of irrigated lowland rice in the Central Plain of Thailand. Agricultural Water Management, 211, 89-97. http://doi.org/10.1016/j.agwat.2018.09.041 
Manjunath, S., \& Kannan, E. (2015). Effect of rural infrastructure on agricultural development: District level analysis in Karnataka (No. 345). Karnataka.

Mikou, M., Rozenberg, J., Koks, E., Fox, C., \& Peralta Quiros, T. (2019). Assessing rural accessibility and rural roads investment needs using open source data (No. Policy Research Working Paper 8746).

Moyo, R., \& Salawu, A. (2019). A survey of communication media preferred by smallholder farmers in the Gweru District of Zimbabwe. Journal of Rural Studies, 0-1. http://doi.org/10.1016/j.jrurstud.2018.12.013

Nan, Y., Gao, Y., \& Zhou, Q. (2019). Rural credit cooperatives' contribution to agricultural growth: Evidence from China. Agricultural Finance Review, 79(1), 119-135. http://doi.org/http://dx.doi.org/10.1108/09564230910978511

Narayanamoorthy, A., \& Hanjra, M. A. (2006). Rural infrastructure and agricultural output linkages: A study of 256 Indian districts. Indian Journal of Agricultural Economics, 61(3), 444-459.

Narula, S. A., \& Bhattacharyya, S. (2017). Off-grid electricity interventions for cleaner livelihoods: A case study of value chain development in Dhenkanal district of Odisha. Journal of Cleaner Production, 142, 191-202. http://doi.org/10.1016/j.jclepro.2016.07.176

Nonvide, G. M. A., Sarpong, D. B., Kwadzo, G. T. M., Anim-Somuah, H., \& Gero, A. F. (2017). Farmers' perceptions of irrigation and constraints on rice production in Benin: a stakeholder consultation approach. International Journal of Water Resources Development, 0627(May), 1-21. http://doi.org/10.1080/07900627.2017.1317631

Nyaga, J., \& Nzulwa, J. (2017). Strategic factors affecting access to credit facilities by smallholder dairy farmers in. Journal of Management, 4(2), 865-888.

Ojochenemi, P. A., Gabriel, R., \& Ogwuche, J. (2017). An Analysis of Women Farmers in Rice Production in Donga Local Government Area of Taraba State. International Journal of Emerging Trends in Social Sciences, 1(1), 16-21.

Osanyinlusi, O. I., \& Adenegan, K. O. (2016). The determinants of rice farmers' productivity in Ekiti. Greener Journal of Agricultural Sciences, 6(2), 049-058.

Owens, T., Hoddinott, J., \& Kinsey, B. (2003). The impact of agricultural extension on farm production in resettlement areas of Zimbabwe. Economic Development and Cultural Change, 51(2), 337-357. http://doi.org/10.1086/346113

Pallant, J. (2007). SPSS Survival Manual A Step by Step Guide to Data Analysis Using SPSS 15 for Windows (3rd Editio). England: McGraw Hill Open University Press.

Pavel, A., \& Moldovan, O. (2019). Determining local economic development in the rural areas of Romania. Exploring the role of exogenous factors. Sustainability (Switzerland), 11(2). http://doi.org/10.3390/su11010282

Pender, J., \& Gebremedhin, B. (2007). Determinants of agricultural and land management practices and impacts on crop production and household income in the highlands of Tigray, Ethiopia. Journal of African Economies, 17(3), 395-450. http://doi.org/10.1093/jae/ejm028

Ragasa, C., \& Chapoto, A. (2017). Limits to green revolution in rice in Africa: The case of Ghana. Land Use Policy, 66(April), 304-321. http://doi.org/10.1016/j.landusepol.2017.04.052

Ren, C., Liu, S., Van Grinsven, H., Reis, S., Jin, S., Liu, H., \& Gu, B (2019). The impact of farm size on agricultural sustainability. Journal of Cleaner Production. http://doi.org/10.1016/J.JCLEPRO.2019.02.151

Roberts, L. C., Otieno, D. J., \& Nyikal, R. A. (2017). An analysis of determinants of access to and use of credit by smallholder farmers in Suakoko district , Liberia, 12(24), 2093-2100. http://doi.org/10.5897/AJAR2017.12386

Salkind, N. J. (1997). Exploring Research (3rd ed.). Upper Saddle River, NJ: Prentice Hall.

Sheng, Y., Ding, J., \& Huang, J. (2019). The Relationship between Farm Size and Productivity in Agriculture: Evidence from Maize Production in Northern China. American Journal of Agricultural Economics, OO(0), 1-17. http://doi.org/10.1093/ajae/aay104

Stewart, W. M., Dibb, D. W., Johnston, A. E., \& Smyth, T. J. (2005). The contribution of commercial fertilizer nutrients to food production. Agronomy Journal, 97(1), 1-6. http://doi.org/10.2134/agronj2005.0001

Tabachnick, B. G., \& Fidell, L. S. (2013). Using Multivariate Statistics (6th ed.). Boston, MA: Pearson.

Tashikalma, A. K., Giroh, D. Y., \& Ugbeshe, V. . (2014). Swamp rice production in Ogoja Local Government Area of Cross River State, Nigeria: An imperative for rice value chain of the agricultural transformation agenda. International Journal of Agricultural Policy and Research, 2(August), 281-287.

Teruel, R. G., \& Kuroda, Y. (2005). Public infrastructure and productivity growth in Philippine agriculture, $1974-2000$. Journal of Asian Economics, 16, 555-576. http://doi.org/10.1016/j.asieco.2005.04.011

Tiwasing, P., Dawson, P., \& Garrod, G. (2019). The relationship between micronutrient intake and labour productivity: Evidence from rice-farming households in Thailand. Outlook on Agriculture, 1-8. http://doi.org/10.1177/0030727019829080

Uduma, B. U., Samson, O. A., \& Mure, U. A. (2016). Irrigation potentials and rice self-sufficiency in Nigeria: A review. African Journal of Agricultural Research, 11(5), 298-309. http://doi.org/10.5897/AJAR2015.10284

Wang, J., Chen, Z. K., Gupta, D. S., \& Huang, Z. (2015). "Is small still beautiful? A comparative study of rice farm size and productivity in China and India."' China Agricultural Economic Review, 7(3), 484-509.

Yamaguchi, T., Tuan, L. M., Minamikawa, K., \& Yokoyama, S. (2019). Assessment of the relationship between adoption of a knowledge-intensive water-saving technique and irrigation conditions in the Mekong Delta of Vietnam. Agricultural Water Management, 212(February 2018), 162-171. http://doi.org/10.1016/j.agwat.2018.08.041

Yan, J., Chen, C., \& Hu, B. (2019). Farm size and Production efficiency in Chinese agriculture: output and profit. China Agricultural Economic Review, 11(1), 20-38. http://doi.org/10.1108/17561371311294829

Zhang, T., Chen, A., Liu, J., Liu, H., Lei, B., Zhai, L., ... Wang, H. (2017). Cropping systems affect paddy soil organic carbon and total nitrogen stocks (in rice-garlic and rice-fava systems) in temperate region of southern China. Science of the Total Environment, 609, 1640-1649. http://doi.org/10.1016/j.scitotenv.2017.06.226

Zhang, X., \& Fan, S. (2004). How productive is infrastructure? A new approach and evidence from rural India. American Journal of Agricultural Economics, 86(May), 492-501.

Zhong, M., Zhu, Y., Chen, Q., Liu, T., \& Cai, Q. (2019). Does household engagement in concurrent business affect the farm size-technical efficiency relationship ingrain production? China Agricultural Economic Review, 11(1), 125-142. http://doi.org/10.1108/17561371311294829

Zhu, Z. L., \& Chen, D. L. (2002). Nitrogen fertilizer use in China contributions to food production, impacts on the environment and best management strategies. Nutrient Cycling in Agroecosystems, 63(2), 117-127.

Appendix -A

Table 4. Independent samples T-test for equality of means Leven Test for equality of variance

\begin{tabular}{|c|c|c|c|c|c|c|c|c|c|c|}
\hline \multirow{2}{*}{ 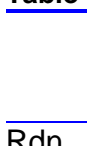 } & \multirow{2}{*}{ 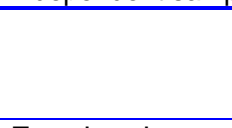 } & \multirow{2}{*}{$\mathbf{F}$} & \multirow{2}{*}{ Sig. } & \multirow[t]{2}{*}{$\mathbf{t}$} & \multirow{2}{*}{ Df } & \multirow{2}{*}{$\begin{array}{l}\text { Sig. (2- } \\
\text { tailed) }\end{array}$} & \multirow{2}{*}{$\begin{array}{l}\text { Mean } \\
\text { Difference }\end{array}$} & \multirow{2}{*}{$\begin{array}{l}\text { Std. Error } \\
\text { Difference }\end{array}$} & \multicolumn{2}{|c|}{95 Conf. of Interval } \\
\hline & & & & & & & & & $\begin{array}{l}\text { The } \\
\text { Lower }\end{array}$ & $\begin{array}{l}\text { Difference } \\
\text { Upper }\end{array}$ \\
\hline $\mathrm{Rdn}$ & $\begin{array}{l}\text { Equal variance } \\
\text { (Assumed) }\end{array}$ & 19.094 & .000 & -.064 & 654 & .949 & -.00419 & .06568 & .13316 & .12479 \\
\hline & $\begin{array}{l}\text { Equal variance } \\
\text { (Not assumed) }\end{array}$ & & & .055 & 237.948 & .956 & -.00419 & .07585 & -.15362 & .14524 \\
\hline Fsz & $\begin{array}{l}\text { Equal variance } \\
\text { (Assumed) }\end{array}$ & 74.029 & .000 & 4.887 & 654 & .000 & .26434 & .05409 & .15814 & .37055 \\
\hline
\end{tabular}




\begin{tabular}{|c|c|c|c|c|c|c|c|c|c|c|}
\hline & & $F$ & Sig. & $t$ & Df & $\begin{array}{l}\text { Sig. (2- } \\
\text { tailed) }\end{array}$ & $\begin{array}{l}\text { Mean } \\
\text { Difference }\end{array}$ & $\begin{array}{l}\text { Std. Error } \\
\text { Difference }\end{array}$ & $\begin{array}{l}95 \text { Conf. } \\
\text { The } \\
\text { Lower }\end{array}$ & $\begin{array}{l}\text { Interval } \\
\text { Difference } \\
\text { Upper }\end{array}$ \\
\hline & $\begin{array}{l}\text { Equal variance } \\
\text { (Not assumed) }\end{array}$ & & & 3.971 & 220.003 & .000 & .26434 & .06657 & .13315 & .39554 \\
\hline \multirow[t]{2}{*}{$\operatorname{Irg}$} & $\begin{array}{l}\text { Equal variance } \\
\text { (Assumed) }\end{array}$ & 50.499 & .000 & 6.686 & 654 & .000 & .50878 & .07610 & .35935 & .65821 \\
\hline & $\begin{array}{l}\text { Equal variance } \\
\text { (Not assumed) }\end{array}$ & & & 5.606 & 228.369 & .000 & .50878 & .09076 & .32995 & .68762 \\
\hline \multirow[t]{2}{*}{ Etr } & $\begin{array}{l}\text { Equal variance } \\
\text { (Assumed) }\end{array}$ & 25.580 & .000 & .103 & 654 & .918 & .00964 & .09380 & -.17455 & .19383 \\
\hline & $\begin{array}{l}\text { Equal variance } \\
\text { (Not assumed) }\end{array}$ & & & .092 & 249.459 & .927 & .00964 & .10467 & -.19651 & .21579 \\
\hline \multirow[t]{2}{*}{ Com } & $\begin{array}{l}\text { Equal variance } \\
\text { (Assumed) }\end{array}$ & 92.244 & .000 & 6.735 & 654 & .000 & .39916 & .05927 & .28277 & .51554 \\
\hline & $\begin{array}{l}\text { Equal variance } \\
\text { (Not assumed) }\end{array}$ & & & 5.214 & 208.808 & .000 & .39916 & .07655 & .24824 & .55007 \\
\hline \multirow[t]{2}{*}{ Ftz } & $\begin{array}{l}\text { Equal variance } \\
\text { (Assumed) }\end{array}$ & 69.462 & .000 & -1.252 & 654 & .211 & -.06083 & .04860 & -.15626 & .03460 \\
\hline & $\begin{array}{l}\text { Equal variance } \\
\text { (Not assumed) }\end{array}$ & & & -.992 & 214.078 & .322 & -.06083 & .06130 & -.18166 & .06000 \\
\hline \multirow[t]{2}{*}{ Mkt } & $\begin{array}{l}\text { Equal variance } \\
\text { (Assumed) }\end{array}$ & 35.276 & .000 & .174 & 654 & .862 & .01247 & .07173 & -.12837 & .15332 \\
\hline & $\begin{array}{l}\text { Equal variance } \\
\text { (Not assumed) }\end{array}$ & & & .150 & 236.435 & .881 & .01247 & .08324 & -.15151 & .17645 \\
\hline \multirow[t]{2}{*}{ Crd } & $\begin{array}{l}\text { Equal variance } \\
\text { (Assumed) }\end{array}$ & 14.034 & .000 & .478 & 654 & .633 & .03531 & .07384 & -.10969 & .18030 \\
\hline & $\begin{array}{l}\text { Equal variance } \\
\text { (Not assumed) }\end{array}$ & & & .431 & 251.894 & .667 & .03531 & .08184 & -.12588 & .19649 \\
\hline \multirow[t]{2}{*}{ Ext } & $\begin{array}{l}\text { Equal variance } \\
\text { (Assumed) }\end{array}$ & 6.626 & .010 & -1.445 & 654 & .149 & -.12229 & .08462 & -.28845 & .04388 \\
\hline & $\begin{array}{l}\text { Equal variance } \\
\text { (Not assumed) }\end{array}$ & & & -1.362 & 269.195 & .174 & -.12229 & .08980 & -.29909 & .05451 \\
\hline
\end{tabular}

Table 6. Correlations among the exogenous variables

\begin{tabular}{|c|c|c|c|c|c|c|c|c|c|}
\hline & Rdn & Fsz & Irg & Etr & Com & Ftz & Crd & Mkt & Ext \\
\hline Rdn & 1 & & & & & & & & \\
\hline Fsz & 0.404 & 1 & & & & & & & \\
\hline Irg & -0.006 & 0.283 & 1 & & & & & & \\
\hline Etr & 0.369 & 0.332 & 0.020 & 1 & & & & & \\
\hline Com & 0.253 & 0.351 & 0.093 & 0.405 & 1 & & & & \\
\hline Ftz & 0.043 & 0.094 & 0.083 & 0.142 & 0.188 & 1 & & & \\
\hline Crd & 0.061 & 0.137 & 0.321 & -0.094 & 0.079 & 0.169 & 1 & & \\
\hline Mkt & 0.017 & 0165 & 0.246 & -0.237 & 0.083 & 0.227 & 0.419 & 1 & \\
\hline Ext & -0.132 & 0.054 & 0.346 & -0.244 & 0.031 & 0.188 & 0.401 & 0.420 & 1 \\
\hline
\end{tabular}

